\title{
Molecular markers and genetic diversity of Plasmodium vivax
}

\author{
Cristiana Ferreira Alves de Brito ${ }^{1 /+}$, Marcelo Urbano Ferreira ${ }^{2}$ \\ 'Laboratório de Malária, Instituto de Pesquisas René Rachou-Fiocruz, Av. Augusto de Lima 1715, 30190-002 Belo Horizonte, MG, Brasil \\ ${ }^{2}$ Departamento de Parasitologia, Instituto de Ciências Biomédicas, Universidade de São Paulo, São Paulo, SP, Brasil
}

\begin{abstract}
Enhanced understanding of the transmission dynamics and population genetics for Plasmodium vivax is crucial in predicting the emergence and spread of novel parasite phenotypes with major public health implications, such as new relapsing patterns, drug resistance and increased virulence. Suitable molecular markers are required for these population genetic studies. Here, we focus on two groups of molecular markers that are commonly used to analyse natural populations of $\mathrm{P}$. vivax. We use markers under selective pressure, for instance, antigen-coding polymorphic genes, and markers that are not under strong natural selection, such as most minisatellite and microsatellite loci. First, we review data obtained using genes encoding for P. vivax antigens: circumsporozoite protein, merozoite surface proteins 1 and $3 \alpha$, apical membrane antigen 1 and Duffy binding antigen. We next address neutral or nearly neutral molecular markers, especially microsatellite loci, providing a complete list of markers that have already been used in P. vivax populations studies. We also analyse the microsatellite loci identified in the P. vivax genome project. Finally, we discuss some practical uses for P. vivax genotyping, for example, detecting multiple-clone infections and tracking the geographic origin of isolates.
\end{abstract}

Key words: malaria - Plasmodium vivax - genetic markers - genetic diversity - multiple-clone infections - microsatellites

Plasmodium vivax, a relatively neglected human malaria parasite, is a major public health challenge for Central and South America, the Middle East, Central, South and Southeast Asia, Oceania and East Africa, where 2.85 billion people are currently at risk of infection and 70-80 million clinical cases are reported each year (Mueller et al. 2009, Guerra et al. 2010). The emergence of drug-resistant strains and severe (sometimes fatal) disease challenges the traditional view of vivax malaria as a benign infection (Price et al. 2009). Recent epidemiological trends in Brazil illustrate the importance of $P$. vivax as a re-emerging pathogen. The annual incidence of Plasmodium falciparum (the predominant malaria parasite species between 1985-1990) decreased steadily during the 1990s, while that of $P$. vivax maintained an upward trend. Both P. falciparum and P. vivax are still transmitted across the Amazon Basin, with rare Plasmodium malariae infections. However, $P$. vivax now causes $85 \%$ of the 315,000 malaria cases reported in this country each year (Oliveira-Ferreira et al. 2010), suggesting that this species may be less susceptible to the malaria control strategies currently used in Brazil.

Understanding the genetic structure of $P$. vivax is essential to accurately describing the transmission dynamics of vivax malaria. Population genetics data are crucial, for example, to predict how fast phenotypes of interest, such as novel antigenic variants, particular relapsing patterns or drug resistance, arise and spread

Financial support: Rede Malária/PRONEX, MS/DECIT, FAPEMIG, FAPEMAT, NIAID, NIH (R01 AI075416-04) (to MUF)

+Corresponding author: cristiana@cpqrr.fiocruz.br CFADB and MUF were supported by CNPq fellowships.

Received 26 April 2011

Accepted 8 June 2011 in natural populations (Zilversmit \& Hartl 2005). The current data on $P$. vivax population genetics lags behind that of $P$. falciparum, primarily due to the scarcity of appropriate genetic markers. As we cannot propagate the parasite in continuous culture in vitro (Udomsangpetch et al. 2008), the phenotypic diversity of natural human infections from $P$. vivax remained unexplored until the early 1990s. Advances in molecular methods, especially implementation of polymerase chain reaction (PCR)based protocols to amplify parasite DNA, allowed for genotyping of malaria parasite samples obtained directly from patient blood, without a preceding in vitro culture step (Kimura et al. 1990). The relative paucity of genetic markers hampers further investigation into the genotypes that underlie phenotypes such as relapse pattern, virulence and drug resistance.

In this review, we broadly classify the available molecular markers into two groups: (i) markers that are clearly under natural selection, that is, markers that map to genome regions associated with adaptive traits and (ii) markers that are neutral or nearly neutral, that is, those that are not obviously influenced by natural selection. The extensive polymorphism found in loci associated with $P$. vivax adaptive traits, such as those coding for surface antigens and drug-resistance (Cui et al. 2003a), reflects the combined effects of the parasite's population history and selective constraints imposed by the host's immunity and drug usage (Escalante et al. 2004). Thus, these loci do not provide much information on the $P$. vivax population structure. Neutral and nearly neutral markers, in contrast, may allow for unbiased estimates of genetic variation, population structure and gene flow in natural parasite populations.

When comparing different markers and parasite typing systems, a clear quantitative definition of genetic diversity is required. One of the most popular methods of summarising genetic diversity levels is to report vir- 
tual heterozygosity $\left(H_{\mathrm{E}}\right)$ values. Virtual $H_{\mathrm{E}}$ is the average probability that a pair of alleles randomly obtained from the population is different. Whenever appropriate, in this review we provide $H_{\mathrm{E}}$ estimates obtained using different markers for different populations.

Molecular markers under selection - Until recently, most genetic markers available for characterising natural $P$. vivax populations were orthologues of previously identified $P$. falciparum antigen-coding genes. The wellcharacterised polymorphic regions in these genes have been extensively used to analyse genetic diversity patterns in P. falciparum (Roy et al. 2008). A similar approach has been explored in vivax-oriented studies (Cui et al. 2003a). The following single-copy genes in P. vivax have often been used in these studies: gaml, coding for the gametocyte antigen $1, c s p$, coding for the circumsporozoite protein (CSP), mspl and msp3alpha, coding for the merozoite surface proteins (MSP)-1 and $3 \alpha$, respectively, amal, coding for the apical membrane antigen 1 , and $d b p$, coding for the Duffy binding protein (DBP) (Table I).

A notable feature of several $P$. vivax surface antigens (including major vaccine-candidate molecules) is tandem arrays of relatively short amino acid motifs. The CSP in P. vivax (PvCSP), an abundant antigen on the surface of sporozoites that has been extensively used as a vaccine development target, has immunodominant B-cell epitopes that map to central repeats between nonrepetitive sequences (Nardin \& Zavala 1998). PvCSP displays two major types of nonapeptide repeats [most commonly GDRA(D/A)GQPA and ANGA(G/D)(N/D)QPG], which define the variants known as VK210 and VK247, respectively (Arnot et al. 1985, Rosenberg et al. 1989) (Fig. 1). Both VK210 and VK247 variants are globally distributed, but geographic biases have been described (Cochrane et al. 1990, Qari et al. 1993a, b). Similar repetitive sequences are found in Brazil, Southeast Asia and Papua New Guinea (Qari et al. 1991, 1992). However, markedly divergent sequence variants were found in isolates from China and North Korea (Mann et al. 1994). Although VK210 and VK247-type sequences often occur in sympatric parasite populations, there are no examples of a hybrid repeat array with both repeat types (Lim et al. 2005).

A third type of repeat unit [APGANQ(E/G)GAA], identical to that described for Plasmodium simiovale, characterises the so-called $P$. vivax-like parasites (Qari et al. 1993a). Although P. vivax-like CSP repeats have been found in parasite isolates across the world, its global distribution remains unconfirmed (Gopinath et al. 1994). In Brazil, $P$. vivax-like parasites have been identified only in mixed-clone infections with VK210-type or VK247-type parasites (Machado \& Póvoa 2000). More recently, complex mixtures of parasites harbouring several PvCSP types and co-infecting the same hosts have been demonstrated by Henry-Halldin et al. (2011) in Papua New Guinea.

The nonapeptide sequences in PvCSP are repeated $\sim 20$ times in the array. Insertions and deletions in the central repeat domain, from either sexual recombination during meiosis or intrahelical strand-slippage events during mitotic DNA replication (McConkey et al. 1990), generate novel CSP variants that may be positively select-

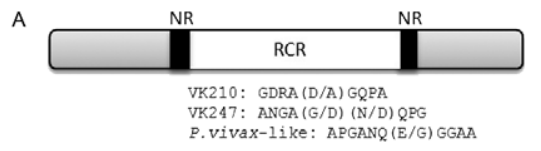

B
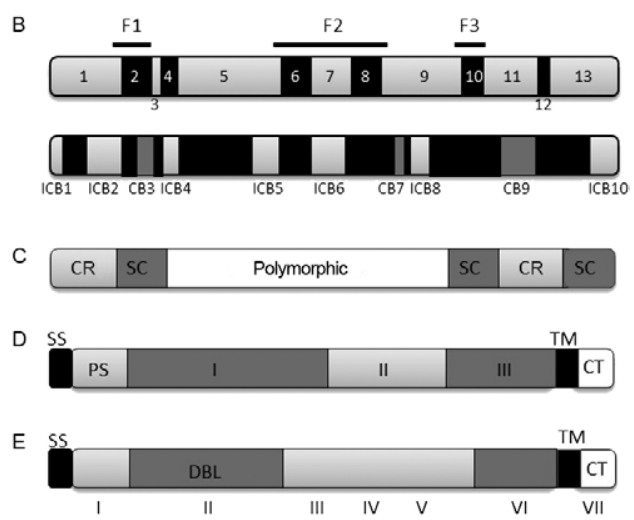

Fig. 1: schematic representation of studied antigens: A: the circumsporozoite protein of Plasmodium vivax (PvCSP) consists of a conserved region (light grey) flanking a repeated central region (RCR) (blank box), which contains immunodominant B-cell epitopes and is flanked by pre and post-repeat specific nonrepetitive sequences (NR) (black boxes). PvCSP displays three types of repeats [GDRA(D/A) GQPA (VK210), ANGA(G/D)(N/D)QPG (VK247)] which are the most prevalent and APGANQ[E/G]GGAA (P. vivax-like); B: the $P$. vivax merozoite surface protein 1 (PvMSP-1) sequence comprises seven conserved blocks (amino acid similarity among PvMSP-1 alleles, $71-85 \%$ ) (light grey boxes) and six variable blocks (amino acid similarity, 21-34\%) (black boxes), described by Putaporntip et al. (2002). For comparison, we also show the original division of PvMSP-1 into interspecies conserved blocks (ICBs) (amino acid similarity $>48 \%$ in pairwise comparisons of MSP-1 orthologues in Plasmodium falciparum, $P$. vivax and Plasmodium yoelii) (light grey boxes), conserved blocks (CBs) (amino acid similarity $>50 \%$ between $P$. falciparum and $P$. vivax, but lower in other pairwise comparisons) (dark grey boxes) and polymorphic blocks (amino acid similarity $<45 \%$ ) (black boxes) (del Portillo et al. 1991). These two methods of portioning PvMSP-1 differ in that Putaporntip et al. (2002) compared intraspecific sequences, while del Portillo et al. (1991) compared between-specific sequences. The F1, F2 and F3 were defined by Imwong et al. (2005) (horizontal bold lines); C: the $P$. vivax merozoite surface protein $3 \alpha$ (PvMSP-3 $\alpha$ ) contains an alanine-rich central polymorphic region (blank box), which could be partially deleted, generating three types of proteins with different sizes. This region is flanked by semi-conserved regions (SC) (grey boxes) and by conserved regions (CR) (light grey boxes); D: the $P$. vivax apical membrane antigen 1 (PvAMA-1) displayed three domains in its ectodomain, referred to as domain I, II and III; E: the P. vivax Duffy binding protein (PvDBP) is schematically divided in seven domains: II [Duffy binding-like domain (DBL)] and VI are cysteine-rich domains. The DBL domain is the most polymorphic and responsible for the interaction with the Duffy antigen at the erythrocyte surface; CT: cytoplasmic tail; PS: pro sequence; SS: signal peptide; TM: transmembrane domain.

ed if the mutant parasites evade a host's immunity. The central repetitive domain of $P$. falciparum CSP (PfCSP) contains extensive variation. This domain consists of a variable number of four-mer NANP and NVDP motif copies without breaking down the tight linkage between polymorphic sites in flanking sequences, as in interhelical exchanges during meiosis (Rich et al. 1997). This pattern suggests that these repeats undergo frequent in- 
TABLE I

Genes encoding antigens used as molecular markers to study field populations of Plasmodium vivax

\begin{tabular}{|c|c|c|c|c|}
\hline Antigen & $\begin{array}{l}\text { Protein } \\
\text { fragment }\end{array}$ & $\begin{array}{l}\text { Population studied } \\
\qquad \text { (n) }\end{array}$ & $\begin{array}{l}\text { Total }^{a} \\
\text { (n) }\end{array}$ & References \\
\hline \multirow[t]{11}{*}{ PvAMA-1 } & Domain I & BRA & 105 & Grynberg et al. (2008) \\
\hline & & & 20 & Rodrigues et al. (2005) \\
\hline & & KOR & 30 & Chung et al. (2003) \\
\hline & & & 22 & Han et al. (2002) \\
\hline & & MYA & 76 & Moon et al. (2010) \\
\hline & & $\begin{array}{l}\text { AFR (5), CHI (5), IND (18), INDO (5), } \\
\text { PHI (148), PNG (23), SI (7), THAI (6) }\end{array}$ & 219 & Figtree et al. (2000) \\
\hline & Domain I, II & IND & 61 & Thakur et al. (2008) \\
\hline & Whole & IND & 11 & Rajesh et al. (2007) \\
\hline & & SRL & 23 & Gunasekera et al. (2007) \\
\hline & & THAI & 231 & Putaporntip et al. (2009) \\
\hline & & VEN & 73 & Ord et al. (2008) \\
\hline \multirow[t]{24}{*}{ PvCSP } & CR & AFG & 202 & Zakeri et al. (2010) \\
\hline & & AZE & 36 & Leclerc et al. (2004) \\
\hline & & BRA & 48 & Machado and Póvoa (2000) \\
\hline & & & 45 & Patil et al. (2010) \\
\hline & & & 32 & Santos-Ciminera et al. (2007) \\
\hline & & & 155 & Storti-Melo et al. (2009) \\
\hline & & Central AME, South AME, AFR, Southeast ASI, IND & 126 & Gopinath et al. (1994) \\
\hline & & $\mathrm{COL}$ & 24 & Hernández-Martínez et al. (2011) \\
\hline & & GUY & 61 & Bonilla et al. (2006) \\
\hline & & IND & 151 & Kim et al. (2006) \\
\hline & & IRA & 144 & Zakeri et al. (2006) \\
\hline & & KOR & 632 & Choi et al. (2010) \\
\hline & & MYA & 116 & Moon et al. (2010) \\
\hline & & PAK & 187 & Zakeri et al. (2006) \\
\hline & & PAK (187), IRA (150) & 337 & Zakeri et al. (2010) \\
\hline & & PNG & 40 & Kolakovich et al. (1996) \\
\hline & & & 507 & Henry-Halldin et al. (2011) \\
\hline & & THAI & 90 & Cui et al. (2003b) \\
\hline & & & 100 & Imwong et al. (2005) \\
\hline & & & 171 & Kain et al. (1993) \\
\hline & & & 17 & Rongnoparut et al. (1995) \\
\hline & CR, NR & BRA (30), PNG (14) & 30 & Qari et al. (1992) \\
\hline & $\mathrm{N}, \mathrm{C}$-end & PHI, CHI, SI, PNG & 18 & Huang et al. (1994) \\
\hline & Whole & $\mathrm{CHI}$ & 16 & Mann et al. (1994) \\
\hline \multirow[t]{13}{*}{ PvDBP } & Whole & $\mathrm{COL}$ & 23 & Martinez et al. (2004) \\
\hline & Domain II-IV & South KOR & 30 & Kho et al. (2001) \\
\hline & Domain II & BRA & 40 & Sousa et al. (2006) \\
\hline & & & 122 & Sousa et al. (2010) \\
\hline & & $\mathrm{COL}$ & 20 & Ampudia et al. (1996) \\
\hline & & COL (18), South KOR (14), PNG (68) & 100 & Cole-Tobian et al. (2002) \\
\hline & & IRA & 75 & Babaeekho et al. (2009) \\
\hline & & PNG & 40 & Kolakovich et al. (1996) \\
\hline & & & 358 & Cole-Tobian et al. (2002) \\
\hline & & & 50 & Tsuboi et al. (1994) \\
\hline & & & 24 & Xainli et al. (2000) \\
\hline & & THAI & 30 & Gosi et al. (2008) \\
\hline & Domain II, III & KOR & 8 & Suh et al. (2001) \\
\hline
\end{tabular}




\begin{tabular}{|c|c|c|c|c|}
\hline Antigen & $\begin{array}{l}\text { Protein } \\
\text { fragment }\end{array}$ & $\begin{array}{l}\text { Population studied } \\
\text { (n) }\end{array}$ & $\begin{array}{c}\text { Total }^{a} \\
\text { (n) }\end{array}$ & References \\
\hline \multirow[t]{29}{*}{ PvMSP-1 } & Pv200L & COL & 26 & Valderrama-Aguirre et al. (2011) \\
\hline & $925 \mathrm{pb}$ & PHI, CHI, SI, PNG & 18 & Cheng et al. (1993) \\
\hline & BL 2 & BRA (28), VIET (23) & 51 & Hoffmann et al. (2003) \\
\hline & ICBs 2-4 & $\mathrm{COL}$ & 20 & Gutierrez et al. (2000) \\
\hline & \multirow[t]{2}{*}{ ICBs 4,5} & $\begin{array}{l}\text { AFR (5), CHI (10), IND (21), INDO (11), } \\
\text { PHI (97), PNG (21), SI(6), THAI (4) }\end{array}$ & 175 & Figtree et al. (2000) \\
\hline & & KOR & 30 & Kim et al. (2009) \\
\hline & \multirow{12}{*}{$\begin{array}{c}\text { ICBs } 5,6 \\
\text { or } \\
\text { BL } 5\end{array}$} & AZE & 36 & Leclerc et al. (2004) \\
\hline & & BRA & 32 & Santos-Ciminera et al. (2007) \\
\hline & & French GUY & 120 & Veron et al. (2009) \\
\hline & & IND & 25 & Farooq et al. (2009) \\
\hline & & IND (9), COL (11) & 20 & Maestre et al. (2004) \\
\hline & & KOR & 632 & Choi et al. (2010) \\
\hline & & & 25 & Lim et al. (2000) \\
\hline & & MYA & 116 & Moon et al. (2009) \\
\hline & & PNG & 40 & Kolakovich et al. (1996) \\
\hline & & PAK (187), IRA (150) & 337 & Zakeri et al. (2010) \\
\hline & & SRL & 22 & Premawansa et al. (1993) \\
\hline & & THAI & 15 & Putaporntip et al. (1997) \\
\hline & \multirow[t]{2}{*}{ F1-F3 } & IND & 151 & Kim et al. (2006) \\
\hline & & THAI & 100 & Imwong et al. (2005) \\
\hline & F1, F3 & PNG & $93-108$ & Koepfli et al. (2009) \\
\hline & \multirow[t]{2}{*}{$\mathrm{MSP}^{-1}{ }_{42}$} & SRL & 95 & Dias et al. (2011) \\
\hline & & IND & 33 & Thakur et al. (2008) \\
\hline & \multirow[t]{2}{*}{ MSP-1 $_{19}$} & BRA & 28 & Soares et al. (1999) \\
\hline & & GUY & 61 & Bonilla et al. (2006) \\
\hline & C-terminal & PHI (4) THAI (3) SI (8), PNG (1), South East ASI (4) & 20 & Pasay et al. (1995) \\
\hline & \multirow[t]{3}{*}{ Whole } & THAI (20), BRA (8), BAN (5), South KOR (4), VAN (2), IND (1) & 40 & Putaporntip et al. (2002) \\
\hline & & KOR & 45 & Han et al. (2011) \\
\hline & & TUR & 30 & Zeyrek et al. (2010) \\
\hline \multirow[t]{16}{*}{ PvMSP-3 $\alpha$} & \multirow[t]{15}{*}{ NA } & IND & 151 & Kim et al. (2006) \\
\hline & & $\mathrm{COL}$ & 55 & Cristiano et al. (2008) \\
\hline & & French GUY & 120 & Veron et al. (2009) \\
\hline & & IND & 27 & Prajapati et al. (2010) \\
\hline & & IRA & 144 & Zakeri et al. (2006) \\
\hline & & MYA & 116 & Moon et al. (2009) \\
\hline & & PAK & 50 & Khatoon et al. (2010) \\
\hline & & PAK (187), IRA (150) & 337 & Zakeri et al. (2010) \\
\hline & & PER & 186 & Sutton et al. (2009) \\
\hline & & PNG & 28 & Bruce et al. (2000) \\
\hline & & & 11 & Mueller et al. (2002) \\
\hline & & PNG (39), IND (4), Sudan (1), SRL (1) & 45 & Bruce et al. (1999) \\
\hline & & South KOR & 24 & Han et al. (2004) \\
\hline & & THAI & 90 & Cui et al. (2003b) \\
\hline & & VEM & 58 & Ord et al. (2005) \\
\hline & Whole & THAI & 17 & Mascorro et al. (2005) \\
\hline
\end{tabular}

a: number of $P$. vivax infected patients studied in genotyping; AFG: Afghanistan; AFR: Africa; AMA: apical membrane antigen; AME: America; ASI: Asia; AZE: Azerbaijan; BAN: Bangladesh; BL: polymorphic block (Putaporntip et al. 1997); BRA: Brazil; CHI: China; COL: Colombia; CR: central repeatitive; CSP: circumsporozoite protein; DBP: Duffy binding protein; ICB: interspecies conserved blocks (del Portillo et al. 1991); IND: India; INDO: Indonesia; IRA: Iran; KOR: Korea; MSP: merozoite surface protein; MYA: Myanmar; NA: not applied restriction fragment length polymorphism-polymerase chain reaction; NR: non-repetitive; PAK: Pakistan; PER: Peru; PHI: Philippines; PNG: Papua New Guinea; Pv: Plasmodium vivax; SI: Solomon Islands; SRL: Sri Lanka; THAI: Thailand; TUR: Turkey; VAN: Vanuatu; VEN: Venezuela; VIET: Vietnam. 
trahelical recombination that either add or delete repeat units during mitotic DNA replication (Fig. 2), as other short repeats, such as microsatellite and minisatellitetype sequences (Levinson \& Gutman 1987). Frequent mitotic recombination coupled with positive selection of new variants might accelerate sequence evolution even where meiotic recombination and outcrossing are relatively uncommon in malaria parasite populations (Rich et al. 2000). In length variation arrays, whether length variation affects B-cell epitope recognition is uncertain, but the conformational nature of repetitive epitopes in PfCSP (Monette et al. 2001) supports this hypothesis.

We have recently examined whether similar recombination mechanisms create significant variation in the PvCSP repeat arrays, which consist of longer (9-mer) repetitive motifs (Patil et al. 2010). We investigated patterns of sequence diversity in PvCSP encoding gene alleles in sympatric $P$. vivax isolates from an area of low malaria endemicity in Brazil. In these isolates, we used single-nucleotide polymorphism typing to examine the haplotype structure of chromosome 8 , where the $\mathrm{PvC}$ $\mathrm{SP}$ encoding gene is located. We sought to determine whether the repetitive domain in the $c s p$ locus was significantly diverse under conditions of low malaria endemicity, which reduces effective meiotic recombination rates in local parasites. We confirmed previous findings (Arnot et al. 1985, 1990, Qari et al. 1992, 1994, Mann et al. 1994) of substantial nucleotide sequence diversity in repeat arrays from 45 isolates. They were analysed using nine different $c s p$ alleles, each with a unique arrangement of six different nonapeptide repeat sequences, and all were of the VK210 type. Notably, different nucleotide motifs, termed repeat allotypes, coded for the same VK210-type repeat units, indicating that some conservation is maintained at the amino acid level (putatively due to functional constraints), but not necessarily at the nucleotide level (Rich et al. 1997, 2000). Most repeat units in the same csp allele were either identical or nearly identical to each other, consistent with their recent expansion in the repeat array. We found strong linkage disequilibrium at sites across the chromosome 8 segment flanking the csp locus, consistent with rare meiotic recombination in this region. This suggests that repeat array diversity may not be severely constrained by low meiotic recombination rates that are typical in areas with low malaria endemicity. New repeat variants may be readily created by nonhomologous recombination events with potential implications for PvCSP-based vaccine development.

The MSP-1 and $3 \alpha$ are additional examples of bloodstage vaccine-candidate antigens with repetitive arrays. The 200-kDa MSP 1 in P. vivax (PvMSP-1), originally described at the molecular level by del Portillo et al. (1991), is a major target of naturally acquired (Nogueira et al. 2006) and vaccine-induced immunity (Yang et al. 1999, Herrera et al. 2007). The protein contains six highly polymorphic domains (4 of them repetitive) flanked by seven fairly conserved sequences (Putaporntip et al. 2002) (Fig. 1). Sequence analysis has confirmed that blocks 1, 3 and 5 in PvMSP-1 are conserved at the protein level, while blocks 2, 4 and 6 are highly variable
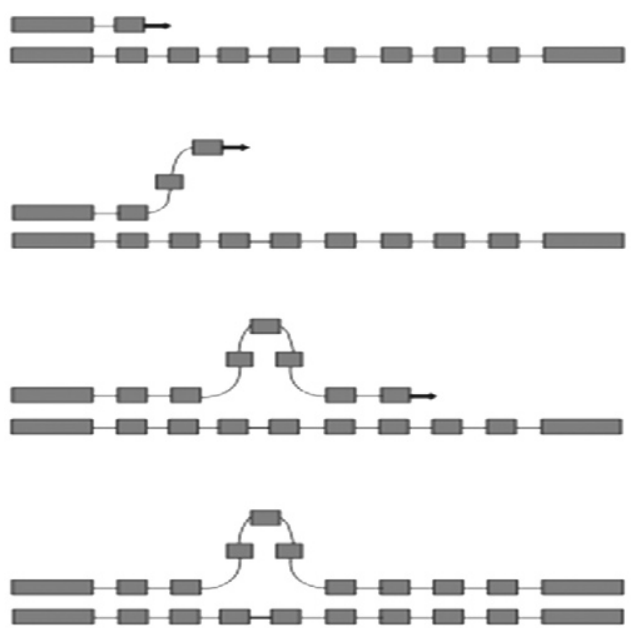

Fig. 2: a strand-slippage event in a repetitive sequence during mitotic DNA replication. The nascent (upper) strand becomes displaced from the parental (lower) strand during DNA replication and re-anneals out of phase, inserting a repeat motif (grey square) without changing nonrepetitive flanking sequences (grey rectangles). A similar slippage process in the parental strand would delete a one repeat motif from the nascent strand. These processes are suggested to generate variation in repeat arrays of surface malarial antigens, such as circumsporozoite protein of Plasmodium vivax (PvCSP) and in minisatellite and microsatellite-type sequences.

(Kolakovich et al. 1996, Figtree et al. 2000, Hoffmann et al. 2003, Bastos et al. 2007, Farooq et al. 2009, Kim et al. 2009, Veron et al. 2009, Zakeri et al. 2010).

The extensive sequence divergence in variable domains of PvMSP-1 (amino acid similarity, 21-34\%) has been maintained by balanced selection, most likely as a result of variant-specific immune pressure (Putaporntip et al. 2006). However, the extent to which PvMSP-1 sequence diversity affects immune recognition for this major malaria-vaccine candidate antigen remains uncertain. To address this topic, we have recently compared naturally acquired antibody responses to three polymorphic domains and the highly conserved PvMSP-1 C-terminal domain in a rural, malaria-exposed Amazonian cohort. We expressed 15 recombinant proteins corresponding to PvMSP-1 variants commonly found in local parasites and showed that less than one-third had detectable $\operatorname{IgG}$ antibodies to at least one expressed variant of blocks 2 , 6 and 10 . However, $54.3 \%$ recognised the invariant Cterminal domain PvMSP- $1_{10}$. Although the proportion of PvMSP-1 variant responders increased substantially during subsequent acute $P$. vivax infections, the specificity of IgG antibodies did not necessarily match the PvMSP-1 variant(s) found in infecting parasites (Bastos et al. 2007). The mechanisms underlying the limited immune recognition of PvMSP-1 variants that are known to circulate in a given endemic area remain unclear.

$P$. vivax evidences an allelic form diversity across the $m s p l$ gene. In contrast, $P$. falciparum exhibits a clear allelic dimorphism over a long region in the mspl locus (that is, sequences can be grouped into 1 of 2 major allelic types, MAD20 and K1) (Roy et al. 2008). Fre- 
quent meiotic recombination events that shuffle different sequence types to generate new alleles are responsible for the mosaic structure of PvMSP-1 (Putaporntip et al. 1997, 2002). Recently, Han et al. (2011) compared PvMSP-1 alleles from re-emergent $P$. vivax parasites collected in the Republic of Korea over the past decade. They showed an increase in allelic diversity for variable domains of this protein, suggesting that recombination independently changed protein domains. Moreover, the greater similarity between allelic sequences within $P$. vivax than between $P$. vivax and closely related species was taken as evidence that polymorphisms in $P$. vivax arose recently. This is in stark contrast to the $P$. falciparum pattern, wherein different alleles are estimated to have diverged more than 25 million years ago (Polley et al. 2005). However, the cause for the large differences in this genetic history for these highly divergent parasites remains obscure. It may reflect either the significantly different sequence structure of the orthologues, different molecular functions for the gene in the two species, a different population history, or another event.

Proteolytic processing of PvMSP-1 generates a C-terminal fragment of $42 \mathrm{kDa}\left(\mathrm{PvMSP}_{42}\right)$, which is subsequently cleaved to generate two smaller fragments with apparent molecular masses $33 \mathrm{kDa}\left(\mathrm{PvMSP}-1_{33}\right)$ and $19 \mathrm{kDa}$ $($ PvMSP-1 19$)$. Only the small, PvMSP-1 $1_{19}$ fragment remains at the merozoite surface during and after erythrocyte invasion (Holder 2009). Limited polymorphism has been observed in the C-terminal 19-kD PvMSP-1 fragment, with only two polymorphic sites (Soares et al. 1999, Dias et al. 2011). PvMSP-1 ${ }_{42}$, like PfMSP-1 ${ }_{42}$, exhibits extensive genetic polymorphism in natural infections (Escalante et al. 1998, Conway et al. 2000, Putaporntip et al. 2002, Pacheco et al. 2007, Thakur et al. 2008, Dias et al. 2011).

The $P$. vivax $m s p 3 \alpha$ gene encodes a MSP with an apparent molecular mass ranging from $148-150 \mathrm{kDa}$. The protein contains an alanine-rich central domain that is predicted to form a coiled-coil tertiary structure (Galinski et al. 1999) (Fig. 1). The gene coding for the MSP-3 $\alpha$ (PvMSP$3 \alpha$ ) is highly polymorphic and its variability has been assessed by restriction fragment length polymorphism-PCR analysis (Bruce et al. 1999). The suitability of PvMSP-3 $\alpha$ as a molecular marker has been confirmed in several geographic parasite populations: Papua New Guinea (Bruce et al. 1999), Thailand (Cui et al. 2003b, Mascorro et al. 2005), Pakistan and Iran (Zakeri et al. 2006, 2010, Khatoon et al. 2010), Venezuela (Ord et al. 2005), Peru (Sutton et al. 2009), Colombia (Cristiano et al. 2008), India (Prajapati et al. 2010) and French Guiana (Veron et al. 2009). However, classifying restriction fragments according to size after electrophoresis is relatively subjective, which hampers large-scale analyses and reduces comparisons between studies. In addition, complex restriction patterns generated by mixed-clone infections may be difficult to interpret.

The P. vivax apical membrane antigen-1 (PvAMA-1) is an immunogenic, type 1 integral membrane protein, which is expressed at the apical surface of merozoites and sporozoites. It seems to play a role in erythrocyte and hepatocyte invasion (Hodder et al. 2001, Silvie et al. 2004). A number of studies have addressed polymorphism in that PvAMA-1 encoding gene in various parts of the world, such as Asia, Oceania and South America (Cheng \& Saul 1994, Figtree et al. 2000, Han et al. 2002, Chung et al. 2003, Rodrigues et al. 2005, Gunasekera et al. 2007, Rajesh et al. 2007, Grynberg et al. 2008, Thakur et al. 2008, Moon et al. 2010). The PvAMA-1 protein includes three extracellular domains, known as domains I, II and III (Pizarro et al. 2005) (Fig. 1). Most studies show a high degree of genetic variability in domain I (Ord et al. 2008, Thakur et al. 2008, Putaporntip et al. 2009), while the Sri Lanka domain II is the most polymorphic (Gunasekera et al. 2007). A comparison of PvAMA-1 domain I sequences from 320 worldwide isolates revealed a striking divergence between Old World populations and those from Brazil (Grynberg et al. 2008, Putaporntip et al. 2009). Sequence analysis of Sri Lankan isolates suggested that balancing selection maintains polymorphism at the $P$. vivax amal locus (Gunasekera et al. 2007), while no strong evidence for balancing selection was found in Thailand (Putaporntip et al. 2009). A number of studies have reported a substantially lower variability at this locus in $P$. vivax than in P. falciparum, implying that natural selection acts differently at this locus in the two species (Gunasekera et al. 2007, Ord et al. 2008, Putaporntip et al. 2009).

P. vivax DBP (PvDBP) plays an important role in the formation of an irreversible junction between $P$. vivax merozoites and its receptor, Duffy antigen/receptor for chemokines (DARC), at the surface of immature red blood cells (reticulocytes). This is a key step in host cell invasion (Singh et al. 2005, Galinski \& Barnwell 2009). In vitro, antibodies against PvDBP inhibit DBP binding to DARC and block invasion of human erythrocytes (Michon et al. 2000, Grimberg et al. 2007, Ceravolo et al. 2008). The most polymorphic segment of this protein is the erythrocyte-binding motif, a 170 amino-acid stretch located in the cysteine-rich domain II (Ranjan \& Chitnis 1999, VanBuskirk et al. 2004, Hans et al. 2005) (Fig. 1). This segment of the protein has been used as molecular marker in genetic population studies of field isolates from Papua New Guinea (Tsuboi et al. 1994, Xainli et al. 2000), Colombia (Ampudia et al. 1996), South Korea (Kho et al. 2001), Brazil (Sousa et al. 2006, 2010) and Thailand (Gosi et al. 2008). Recently, the importance of selective diversifying pressure has been shown for specific regions of the protein structure (Sousa et al. 2010).

Although molecular epidemiological studies using $P$. vivax gam 1 gene have revealed variability in $P$. vivax isolates from Sri Lanka (Snewin et al. 1995), Korea (Kho et al. 2001) and India (Prajapati et al. 2006), amplification of this gene has been associated with artefacts (Imwong et al. 2001, 2005). For this reason, P. vivax gaml is no longer used as a reliable genetic marker.

Neutral or nearly neutral molecular markers - Feng et al. (2003) described 33 tandem repeat (TR) arrays consisting of repeat units with four or more nucleotides. However, not much diversity was revealed by analysing these arrays in four monkey-adapted $P$. vivax strains (India VII, Salvador-I, Belem, Thai-NYU). Leclerc et al. (2004) used the eight most polymorphic TR loci described by Feng et al. (2003) to show much more variability in TRs than microsatellites in isolates from dif- 
ferent endemic areas. However, little TR diversity was found within populations (Tables II, III). Rezende et al. (2009) selected the five most polymorphic loci from Leclerc's study for their analysis of field isolates from four regions in Brazil. This set of TR markers again revealed relatively little diversity in Brazilian isolates (Table III). Most TR markers had a clearly predominant allele. Moreover, these markers were inefficient in detecting multiple-clone infections and were unable to group the isolates according to their geographical origin (Rezende et al. 2009). As these TR markers map to a $100-\mathrm{kb}$ region in chromosome 8 with many putative protein-coding genes (including $c s p$ ), natural selection is expected to affect them, even if indirectly, as a result of hitchhiking (Feng et al. 2003). Thus, these loci may not be effectively neutral given their proximity to sequences under strong diversifying or purifying selection (Leclerc et al. 2004). An alternative explanation for the low variability in TR loci may include their structure, as they are relatively short arrays consisting of long ( $>6 \mathrm{bp}$ ) repeat units. These sequences are less prone to strand slippage events (Fig. 2) than typical microsatellite-type sequences consisting of long arrays of short repeat motifs.

The current markers of choice for large-scale population genetic studies in eukaryotes are highly polymorphic and short (1-6 bp-long) TRs, known as microsatellites (Schlötterer 1998). In contrast to the $\sim 1,000$ polymorphic microsatellite loci currently available for $P$. falciparum typing, it was demonstrated that a few dozen microsatellite loci are polymorphic in P. vivax field isolates (Table II). Despite these limitations, microsatellite-based stud- ies of the parasite have provided valuable information on $P$. vivax population structure and diversity in the Americas, Asia and Africa (Ferreira et al. 2007, Karunaweera et al. 2007, 2008, Koepfli et al. 2009, Orjuela-Sánchez et al. 2009a, Gunawardena et al. 2010, Rezende et al. 2010, Van den Eede et al. 2010a, b, 2011).

The first microsatellite described for $P$. vivax was a dinucleotide (AT) repeat, used to identify high variability in 89 isolates from Papua New Guinea (Gómez et al. 2003) (Tables II, III). Leclerc et al. (2004) reported low variability in dinucleotide microsatellite loci. In this study, only one of 13 microsatellites showed extensive variability and nine were entirely monomorphic among the eight $P$. vivax populations analysed (Table III). Using a draft of the unpublished $P$. vivax genome, Imwong et al. (2006) designed primer pairs for 11 dinucleotide microsatellites and showed extensive variability in $P$. vivax populations from areas with intermediate to high levels of endemicity. They compared their findings with those of Leclerc et al. (2004) and explained the discrepancy in microsatellite diversity levels as the result of repeat array length at the loci studied. They suggested that microsatellite diversity correlates positively repeat array length, as the rate of strand-slippage events that create diversity increases exponentially with repeat array lengths. Recently, Rezende et al. (2010) corroborated this hypothesis using a set of microsatellites with di, tri and tetra nucleotide repeat units. They highlighted the importance of microsatellite loci structure in genetic diversity studies using malaria parasites. Karunaweera et al. (2007) described a new set of highly polymorphic

TABLE II

Description of molecular markers: minisatellites and microsatellites

used in genetic population analysis of Plasmodium vivax field isolates

\begin{tabular}{|c|c|c|c|c|c|c|c|c|}
\hline \multirow{3}{*}{$\begin{array}{l}\text { Group of } \\
\text { molecular } \\
\text { markers }\end{array}$} & \multicolumn{8}{|c|}{ Number of microsatellites } \\
\hline & \multicolumn{3}{|c|}{ Genomic regions } & \multicolumn{4}{|c|}{$\begin{array}{c}\text { Types of repeat unit } \\
\text { (imperfect and/or composed) })^{b}\end{array}$} & \multirow[b]{2}{*}{ References } \\
\hline & Coding (hypothetical) ${ }^{a}$ & Non-coding & Total & $\mathrm{Di}$ & Tri & Tetra & $>4$ & \\
\hline I & $4(2)$ & 4 & $8^{c}$ & 0 & $1(1)$ & 3 & 4 & Feng et al. (2003) \\
\hline II & 1 & 0 & 1 & 1 & 0 & 0 & 0 & Gomez et al. (2003) \\
\hline III & 1 & 12 & 13 & $13(9)$ & 0 & 0 & 0 & Feng et al. (2003) \\
\hline IV & $2(1)$ & 6 & $11^{d}$ & 11 & 0 & 0 & 0 & Imwong et al. (2006) \\
\hline V & $2(1)$ & 6 & 8 & 0 & 1 & 3 & 4 & Imwong et al. (2007) \\
\hline VI & $13(9)$ & 1 & 14 & 0 & $13(7)$ & $1(1)$ & 0 & Karunaweera et al. (2007) \\
\hline VII & $7(2)$ & 17 & 24 & $7(2)$ & $10(3)$ & 6 & 1 & Joy et al. (2008) \\
\hline VIII & $4(3)$ & 7 & 11 & 4 & 3 & 4 & 0 & Rezende et al. (2010) \\
\hline IX & $3(2)$ & 0 & 3 & 0 & $3(1)$ & 0 & 0 & Van den Eede et al. (2010a) \\
\hline
\end{tabular}

$a$ : number of microsatellites lying in hypothetical proteins among the microsatellites which lie in coding regions; $b$ : number of microsatellites imperfect and/or composed among the total number of microsatellites, with different repeat unit sizes [dinucleotides (Di), trinucleotides (Tri) and tetranucleotides (Tetra) or more than 4 nucleotides]; $c$ : in the original manuscript, these molecular markers were designated as tandem repeats, including minisatellites and microsatellites; $d$ : three loci could not be assigned to chromosomes. 
tricleotide and tetranucleotide microsatellites, which are expected to yield more accurate allele scores than dinucleotide markers (Anderson et al. 1999).

$P$. vivax genome sequencing allowed for further characterisation of a panel including $\sim 160$ microsatellites (Carlton et al. 2008). While searching for a repeat unit with 2-6 nucleotides, the authors found only one microsatellite locus with repeats consisting of more than four nucleotides. Most (76\%) loci had perfect repeat units (Fig. 3A), in contrast with the markers described by Karunaweera et al. (2007). All except one microsatellite were assigned to chromosomes, but their chromosome distribution was clearly heterogeneous. Chromosomes 1 and 4 had the lowest marker density, whereas chromosomes 14 and 9 had the highest density (Fig. 3B). Despite the relatively low AT content in the $P$. vivax genome, when compared with that of $P$. falciparum, $P$. vivax microsatellite-type repeats are particularly AT-rich (Fig. 3C). To characterise polymorphic microsatellite markers, these loci were analysed in eight monkey-adapted $P$. vivax strains (Brazil I, Miami II, Pakchong, Panama I, Nicaragua, Thai II, Vietnam IV and Indonesia XIX). Nineteen markers were monomorphic among these samples, none were polymorphic in all strains and the large majority of markers were polymorphic only in 2-4 strains (Fig. 3D). Further, only one-fourth of the markers shown to be polymorphic in natural $P$. vivax populations were also identified as polymorphic using these eight $P$. vivax strains.
High variability in $P$. vivax isolates has been demonstrated using different sets of microsatellites (Table III). However, this comparison is complicated, as it is difficult to determine how much of the variation depends on the set of markers and how much is due to genetic diversity in the studied populations (Imwong et al. 2007a, Koepfli et al. 2009). Currently, the most widely used markers are a set of 14 polymorphic microsatellites described by Karunaweera et al. (2007), which were used to analyse the population structures of P. vivax in Brazil, Vietnam, Sri Lanka, Myanmar, Ethiopia and Peru (Ferreira et al. 2007, Karunaweera et al. 2008, Gunawardena et al. 2010, Van den Eede et al. 2010a, b, 2011). Using the same set of markers, similar variability was detected in different geographical areas, with $H_{\mathrm{E}}$ ranging from 0.71 in Brazil to 0.86 in Myanmar and Vietnam; only Peru showed a slightly lower variability $\left(H_{\mathrm{E}}=0.58\right)$. More recently, Joy et al. (2008) selected 24 microsatellites of $\sim 160$, described by Carlton et al. (2008), and used them to show local adaptation between mosquito vectors and different genetic populations of $P$. vivax from Mexico. There was no correlation between the number of alleles identified by Carlton et al. (2008) and the variability identified using a large number of $P$. vivax field isolates using the same set of markers by Joy et al. (2008). These data reinforce the uncertainty in using laboratory strains to identify polymorphic markers (Fig. 4). Koepfli et al. (2009) showed high variability in Papua New Guinea isolates using this

\section{TABLE III}

Genetic variability analysis of Plasmodium vivax field populations using minisatellites and microsatellites as molecular markers

\begin{tabular}{|c|c|c|c|c|c|c|}
\hline $\begin{array}{l}\text { MM group } \\
\text { (n) }\end{array}$ & $\mathrm{n}$ & $\begin{array}{l}\text { Geographical origin of isolates } \\
\text { (n) }\end{array}$ & $\begin{array}{l}\text { Alleles }^{a} \\
\mathrm{n}\end{array}$ & $H_{\mathrm{E}}$ & MI & References \\
\hline I & 96 & $\begin{array}{l}\text { AZE (37), THAI (15), TUR (16), } \\
\operatorname{VEN(16),~ETH(8)~}\end{array}$ & $1-8$ & $0.26-0.67$ & NA & Leclerc et al. (2004) \\
\hline I (5) & 44 & BRA & $2-9$ & 0.57 & $0-66$ & Rezende et al. (2009) \\
\hline II & 89 & PNG & 15 & 0.85 & 4.5 & Gomez et al. (2003) \\
\hline III & 108 & $\begin{array}{l}\text { AZE (40), THAI (20), TUR (19), VEN (18), } \\
\text { ETH (7), MOZ (1), PNG (1), SRL (1) }\end{array}$ & $1-9$ & $0.35-0.80$ & NA & Leclerc et al. (2004) \\
\hline IV & 82 & COL (27), IND (27), THAI (28) & $7-18$ & $0.64-0.77$ & NA & Imwong et al. (2006) \\
\hline V & 345 & IND (90), LAO (81), THAI (92), COL (82) & $9-35$ & $0.72-0.79$ & $40-80$ & Imwong et al. (2007) \\
\hline VI & 25 & SRL & $6-13$ & 0.78 & NA & Karunaweera et al. (2007) \\
\hline VI & 74 & BRA & $3-14$ & 0.71 & 48 & Ferreira et al. (2007) \\
\hline VI & 132 & SRL (50), BRA (74), VIET (8) & $9-43$ & $0.65-0.908$ & $60^{b}$ & Karunaweera et al. (2008) \\
\hline VI (12) & 425 & SRI (140), MYA (167), ETH (118) & $3-44$ & $0.75-0.86$ & 65 & Gunawardena et al. (2010) \\
\hline VII & 234 & MEX & $4-8^{d}$ & 0.61 & 16 & Joy et al. (2008) \\
\hline V (2), VI (1) & 93-108 & PNG & $13-67$ & 0.93 & NA & Koefli et al. (2009) \\
\hline VIII & 53 & BRA & $4-31$ & 0.71 & 60 & Rezende et al. (2010) \\
\hline VI, IX & 69 & VIET & $6-41$ & 0.86 & $100^{c}$ & Van den Eede et al. (2010a) \\
\hline VI, IX & 94 & PER & $2-8$ & 0.58 & $11-70^{c}$ & Van den Eede et al. (2010b) \\
\hline
\end{tabular}

$a$ : number of alleles per locus only in P. vivax isolates; $b$ : data for samples collected in 2005; $c$ : including all observed alleles above 100 arbitrary fluorescence units (except for MS16 -> 25\%); $d$ : average per locus; AZE: Azerbaijan; BRA: Brazil; COL: Colombia; ETH: Ethiopia; $H_{\mathrm{E}}$ : heterozigosity expected per population using the set of polymorphic markers; IND: India; LAO: Lao; MEX: Mexico; MI: multiple clone infections; MM: molecular marker group defined in Table I (number of markers used was provided only if was not used all markers of the group); MOZ: Mozambique; MYA: Myanmar; n: number of isolates; NA: not available; PER: Peru; PNG: Papua New Guinea; SRL: Sri Lanka; THAI: Thailand; TUR: Turkey; VEN: Venezuela; VIET: Vietnam. 
set of microsatellites and three selected from other studies (Table II). Rezende et al. (2010) described a set of $11 \mathrm{mi}-$ crosatellites used to show a positive correlation between transmission levels and genetic variability in $P$. vivax isolates from geographical regions in Brazil. Taken together, these data suggest that, regardless of endemicity in the isolates' geographical origin, most studies show that $P$. vivax populations are highly variable across the globe.

Practical uses for P. vivax genotyping - The vast field of infectious disease molecular epidemiology has produced a number of examples involving practical applications for molecular markers in addressing issues of clear biological and public health importance. Here, we briefly review four areas of potential interest: (i) detection of naturally occurring multiple-clone infections, (ii) after-treatment follow-up in clinical trials, (iii) betweenspecies comparisons of genetic diversity levels and (iv) tracking of the geographic origin of infections.

Over the last two decades, molecular markers have revealed that many natural $P$. vivax infections comprise a complex mixture of clonal populations; that is, multipleclone vivax infections are fairly common in human hosts (Havryliuk \& Ferreira 2009). The earliest attempts to in- vestigate the clonal diversity of $P$. vivax isolates in human infections focused on characterisation of phenotypes using monoclonal antibodies or isoenzymes (Udagama et al. 1987, 1990, Joshi et al. 1989), an approach that required blood samples with relatively high parasitaemias. As a rule, multilocus analysis, such as microsatellite typing, detects more multiple-clone infections than single-locus analysis, and augmenting the number of markers increases the chance of detecting multiple clones. For example, in 90 P. vivax isolates from Thailand, Cui et al. (2003b) found a multiple-clone infection rate of $25.6 \%$ using the PvCSP encoding gene alone, 19.3\% using PvMSP-3 $\alpha$ alone and $35.6 \%$ when the markers were combined. Particularly surprising is the extensive clonal diversity of $P$. vivax infections in areas with relatively low malaria transmission, such as Brazil, Colombia and Sri Lanka (Ferreira et al. 2007, Imwong et al. 2007b, Karunaweera et al. 2008, Orjuela-Sánchez et al. 2009a, Gunawardena et al. 2010). The evolutionary and epidemiological consequences of multiple-clone $P$. vivax infections have not been well-investigated. However, experimental rodent malaria models suggest that, for two or more genetically distinct clones in the same host, intra-host competition for limited resources may select for $P$. vivax traits repre-

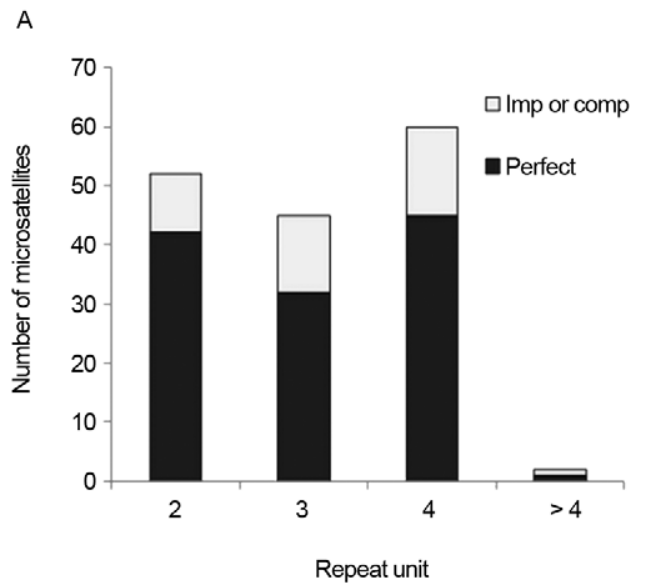

C

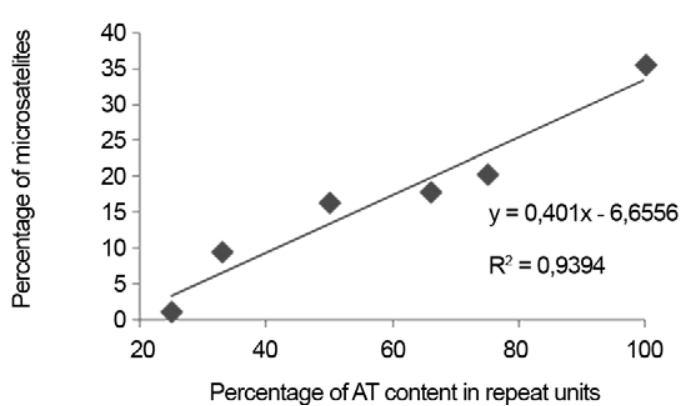

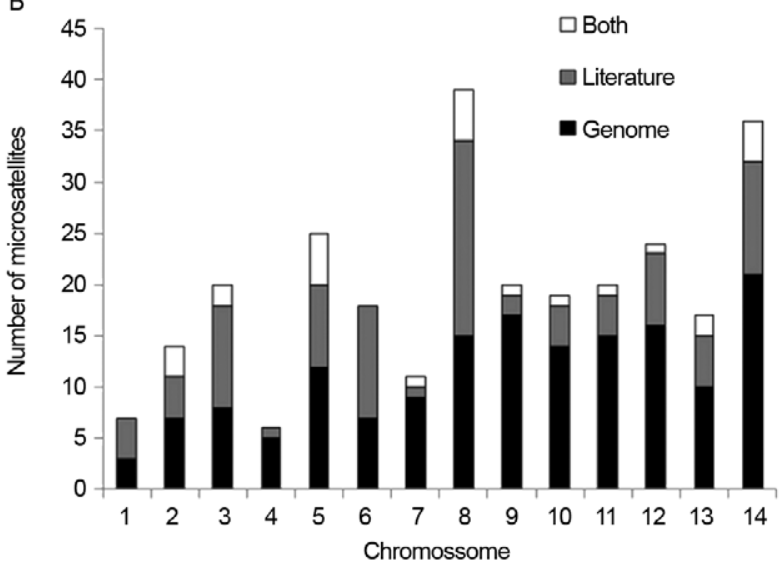

D

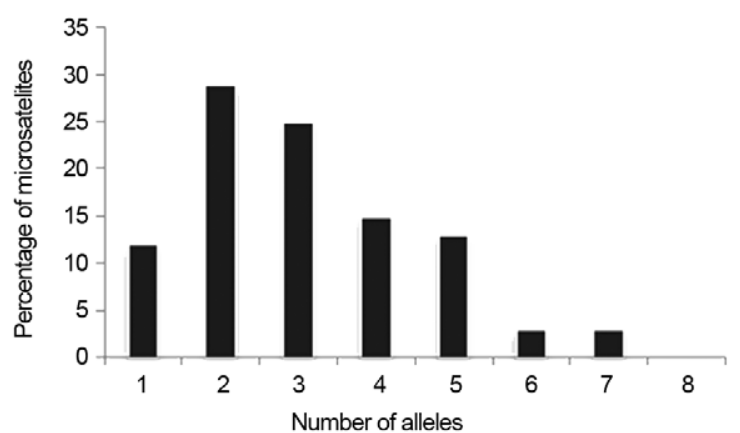

Fig. 3: characterisation of microsatellites identified in the Plasmodium vivax genome project (Carlton et al. 2008). A: number of microsatellites with repeat units composed of either 2, 3, 4 or $>4$ nucleotides. Microsatellites were also divided into either perfect (with only 1 type of tandem repeat unit), composed (comp) (with more than 1 type of repeat unit) or imperfect (imp) (repeat units interspersed with nucleotides); B: distribution of the number of microsatellites among P. vivax chromosomes, including those identified by the genome project, previously described, and present in both; C: positive correlation between percentage of microsatellites and AT content in the repeat units; D: percentage of microsatellites with different numbers of alleles, analysing eight $P$. vivax laboratory lines (Carlton et al. 2008). 


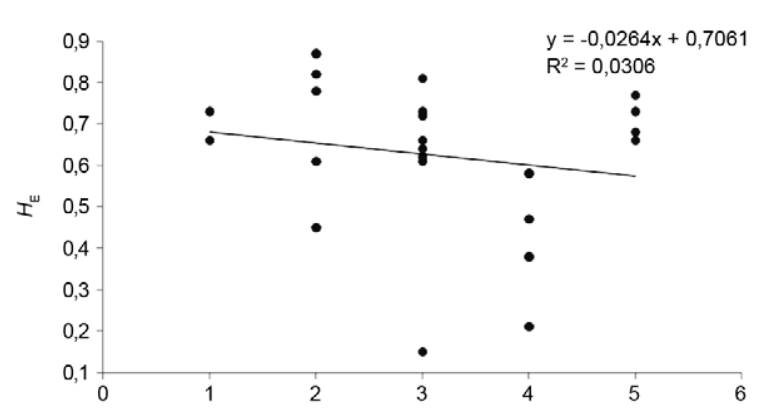

Fig. 4: correlation between number of alleles in eight Plasmodium vivax laboratory lines (Carlton et al. 2008) and the heterozigosity expected $\left(H_{\mathrm{E}}\right)$ in 234 isolates from Mexico (Joy et al. 2008), using the same set of 24 microsatellites.

senting major public health challenges, such as increased virulence, transmissibility and antimalarial drug resistance (reviewed by Havryliuk \& Ferreira 2009).

Molecular markers have also been used to type $P$. vivax infections after drug treatment. Reappearance of parasitaemia after drug treatment can result from either recrudescence of surviving asexual blood-stage parasites; relapse from dormant liver stages, known as hypnozoites; or new infections with unrelated parasites. Paired parasite molecular genotyping distinguishes between recrudescences (with the same genotype as the initial infection) and new infections (with a different genotype). Until recently, relapses were thought to be caused by hypnozoites that are genetically identical to the blood-stage parasites found in primary infections (Craig \& Kain 1996, Kirchgatter \& del Portillo 1998). This suggested that molecular methods could easily discriminate relapses, which would have the same genotype as the primary infection, from new infections, which would have a different genotype. This view has been challenged by the recent discovery of different parasite genotypes in primary infections and relapses for $72 \%$ of $P$. vivax-infected patients from Thailand, India and Myanmar (Imwong et al. 2007b). Accurate detection of multiple-clone $P$. vivax infections is even more important in light of this report. If the primary infection comprises multiple clones, then some of them may have been missed or partially characterised or, even worse, had their alleles combined to create artificial haplotypes during genotyping. Likewise, the relapsing clone could have been either missed or incorrectly typed during the primary infection, leading to a false conclusion that different genotypes were present during the primary and relapse infections. The current consensus is that relapses may originate from reactivation of either the same parasite clone found in the primary bloodstream infection (homologous hypnozoites) or another, genetically different clone (heterologous hypnozoites). Our recent microsatellite analysis of 28 paired acute-infection and recurrence parasites from rural Amazonia revealed only two pairs of identical haplotypes (consistent with recrudescences or reactivation of homologous hypnozoites) and four pairs of related haplotypes (sharing alleles at 11-13 of 14 microsatellites analysed) (Orjuela-Sánchez et al. 2009a).
As the characteristics of endemic settings may influence the genetic diversity of the parasite, noteworthy findings could be obtained from sympatric $P$. vivax and $P$. falciparum isolates that are analysed using similar protocols. Two comparisons of microsatellite diversity in human malaria parasite species co-circulating in the same area in Brazil have been published. Both suggest that $P$. vivax infections are more diverse (that is, they comprise a higher number of alleles and virtual $H_{\mathrm{E}}$ ) and comprise multiple clones more often than P. falciparum infections in rural Amazonia (Ferreira et al. 2007, Orjuela-Sánchez et al. 2009b). As P. vivax currently predominates in Brazil, differences in species-specific transmission levels might translate into differences in genetic diversity. However, we recently found more microsatellite diversity in $P$. vivax compared with $P$. falciparum populations in western Cambodia, where both species are similarly prevalent (MU Ferreira and RM Fairhurst, unpublished observations). Thus, we suggest that the higher microsatellite diversity found in $P$. vivax isolates may reflect greater plasticity in microsatellitetype short repeats for this species.

Finally, standardised molecular methods applied to worldwide populations may also help characterise population or region-specific molecular barcodes. This is essential for tracking the geographic origin of infections. A microsatellite-based analysis of $P$. vivax samples from Sri Lanka, Ethiopia and Myanmar recently showed that parasites may be classified as originating from Asia or Africa with $70-80 \%$ accuracy. This suggests that microsatellite data might be useful in predicting the origin of $P$. vivax parasites (Gunawardena et al. 2010). Further analyses are required to confirm whether microsatellite-based molecular barcodes are useful for determining whether particular infections were either transmitted locally or imported into areas approaching the elimination phase.

\section{REFERENCES}

Ampudia E, Patarroyo M, Patarroyo M, Murillo L 1996. Genetic polymorphism of the Duffy receptor binding domain of Plasmodium vivax in Colombian wild isolates. Mol Biochem Parasitol 78: 269-272.

Anderson TJC, Su XZ, Bockarie M, Lagog M, Day KP 1999. Twelve microsatellite markers for characterization of Plasmodium falciparum from finger-prick blood samples. Parasitology 119: 113-125.

Arnot DE, Barnwell JW, Tam JP, Nussenzweig V, Nussenzweig RS, Enea V 1985. Circumsporozoite protein of Plasmodium vivax: gene cloning and characterization of the immunodoninant epitope. Science 230: 815-818.

Arnot DE, Stewart MJ, Barnwell JW 1990. Antigenic diversity in Thai Plasmodium vivax circumsporozoite proteins. Mol Biochem Parasitol 43: 147-149.

Babaeekho L, Zakeri S, Djadid ND 2009. Genetic mapping of the duffy binding protein (DBP) ligand domain of Plasmodium vivax from unstable malaria region in the Middle East. Am J Trop Med Hyg 80: 112-118.

Bastos MS, da Silva-Nunes M, Malafronte RS, Hoffmann EH, Wunderlich G, Moraes SL, Ferreira MU 2007. Antigenic polymorphism and naturally acquired antibodies to Plasmodium vivax merozoite surface protein 1 in rural Amazonians. Clin Vaccine Immunol 14: 1249-1259. 
Bonilla JA, Validum L, Cumming R, Palmer CJ 2006. Genetic diversity of Plasmodium vivax Pvesp and Pvmsp1 in Guyana, South America. Am J Trop Med Hyg 75: 830-835.

Bruce MC, Galinski MR, Barnwell JW, Donnelly CA, Walmsley M, Alpers MP, Walliker D, Day KP 2000. Genetic diversity and dynamics of Plasmodium falciparum and $P$. vivax populations in multiply infected children with asymptomatic malaria infections in Papua New Guinea. Parasitology 121: 257-272.

Bruce MC, Galinski MR, Barnwell JW, Snounou G, Day KP 1999. Polymorphism at the merozoite surface protein-3 locus of Plasmodium vivax: global and local diversity. Am J Trop Med Hyg 61: 518-525.

Carlton JM, Adams JH, Silva JC, Bidwell SL, Lorenzi H, Caler E, Crabtree J, Angiuoli SV, Merino EF, Amedeo P, Cheng Q, Coulson RM, Crabb BS, del Portillo HA, Essien K, Feldblyum TV, Fernandez-Becerra C, Gilson PR, Gueye AH, Guo X, Kang'a S, Kooij TW, Korsinczky M, Meyer EV, Nene V, Paulsen I, White O, Ralph SA, Ren Q, Sargeant TJ, Salzberg SL, Stoeckert CJ, Sullivan SA, Yamamoto MM, Hoffman SL, Wortman JR, Gardner MJ, Galinski MR, Barnwell JW, Fraser-Liggett CM 2008. Comparative genomics of the neglected human malaria parasite Plasmodium vivax. Nature 455: 757-763.

Cheng Q, Stowers A, Huang TY, Bustos D, Huang YM, Rzepczyk C, Saul A 1993. Polymorphism in Plasmodium vivax MSA1 gene the result of intragenic recombinations? Parasitology 106: 335-345.

Ceravolo I, Souza-Silva F, Fontes CJ, Braga EM, Madureira A, Krettli AU, Souza JM, Brito CF, Adams JH, Carvalho LH 2008. Inhibitory properties of the antibody response to Plasmodium vivax Duffy binding protein in an area with unstable malaria transmission. Scand J Immunol 67: 270-278.

Cochrane AH, Nardin EH, Arruda M, Maracic M, Clavijo P, Collins WE, Nussenzweig RS 1990. Widespread reactivity of human sera with variant repeat of the circumsporozoite protein of Plasmodium vivax. Am J Trop Med Hyg 43: 446-451.

Cole-Tobian JL, Cortés A, Baisor M, Kastens W, Xainli J, Bockarie M, Adams JH, King CL 2002. Age-acquired immunity to a Plasmodium vivax invasion ligand, the Duffy binding protein. J Infect Dis 186: 531-539.

Conway DJ, Cavanagh DR, Tanabe K, Roper C, Mikes ZS, Sakihama N, Bojang KA, Oduola AM, Kremsner PG, Arnot DE, Greenwood BM, McBride JS 2000. A principal target of human immunity to malaria identified by molecular population genetic and immunological analyses. Nat Med 6: 689-692.

Craig AA, Kain KC 1996. Molecular analysis of strains of Plasmodium vivax from paired primary and relapse infections. $J$ Infect Dis 174: 373-379.

Cristiano FA, Pérez MA, Nicholls RS, Guerra AP 2008. Polymorphism in the Plasmodium vivax msp $3 \alpha$ gene in field samples from Tierralta, Colombia. Mem Inst Oswaldo Cruz 103: 493-496.

Cui L, Escalante AA, Imwong M, Snounou G 2003a. The genetic diversity of Plasmodium vivax populations. Trends Parasitol 19: 220-226.

Cui L, Mascorro CN, Fan Q, Rzomp KA, Khuntirat B, Zhou G, Chen H, Yan G, Sattabongkot J 2003b. Genetic diversity and multiple infections of Plasmodium vivax malaria in western Thailand. Am J Trop Med Hyg 68: 613-619.

Cheng Q, Saul A 1994. Sequence analysis of the apical membrane antigen I (AMA-1) of Plasmodium vivax. Mol Biochem Parasitol 65: 183-187.

Choi YK, Choi KM, Park MH, Lee EG, Kim YJ, Lee BC, Cho SH, Rhie HG, Lee HS, Yu JR, Lee JS, Kim TS, Kim JY 2010. Rapid dissemination of newly introduced Plasmodium vivax genotypes in south Korea. Am J Trop Med Hyg 82: 426-432.
Chung JY, Chun EH, Chun JH, Kho WG 2003. Analysis of the Plasmodium vivax apical membrane antigen-1 gene from re-emerging Korean isolates. Parasitol Res 90: 325-329.

del Portillo HA, Longacre S, Khouri E, David PH 1991. Primary structure of the merozoite surface antigen 1 of Plasmodium vivax reveals sequences conserved between different Plasmodium species. Proc Natl Acad Sci USA 88: 4030-4034.

Dias S, Longacre S, Escalante AA, Udagama-Randeniya PV 2011. Genetic diversity and recombination at the C-terminal fragment of the merozoite surface protein-1 of Plasmodium vivax (PvMSP-1) in Sri Lanka. Infect Genet Evol 11: 145-156.

Escalante AA, Cornejo OE, Rojas A, Udhayakumar V, Lal AA 2004. Assessing the effect of natural selection in malaria parasites. Trends Parasitol 20: 388-395.

Escalante AA, Lal AA, Ayala FJ 1998. Genetic polymorphism and natural selection in the malaria parasite Plasmodium falciparum. Genetics 149: 189-202.

Farooq U, Malla N, Dubey ML 2009. Polymorphism in merozoite surface protein-1 gene in north and northwest Indian field isolates of Plasmodium vivax. Indian J Med Res 130: 736-741.

Feng X, Carlton JM, Joy DA, Mu J, Furuya T, Suh BB, Wang Y, Barnwell JW, Su XZ 2003. Single-nucleotide polymorphisms and genome diversity in Plasmodium vivax. Proc Natl Acad Sci USA 100: 8502-8507.

Ferreira MU, Karunaweera ND, da Silva-Nunes M, da Silva NS, Wirth DF, Hartl DL 2007. Population structure and transmission dynamics of Plasmodium vivax in rural Amazonia. J Infect Dis 195: 1218-1226.

Figtree M, Pasay CJ, Slade R, Cheng Q, Cloonan N, Walker J, Saul A 2000. Plasmodium vivax synonymous substitution frequencies, evolution and population structure deduced from diversity in AMA 1 and MSP 1 genes. Mol Biochem Parasitol 108: 53-66.

Galinski M, Barnwell J 2009. Monkey malaria kills four humans. Trends Parasitol 25: 200-204.

Galinski MR, Corredor-Medina C, Povoa M, Crosby J, Ingravallo $\mathrm{P}$, Barnwell JW 1999. Plasmodium vivax merozoite surface protein-3 contains coiled-coil motifs in an alanine-rich central domain. Mol Biochem Parasitol 1011: 131-147.

Gómez JC, McNamara T, Bockarie MJ, Baird JK, Carlton JM, Zimmerman PA 2003. Identification of a polymorphic Plasmodium vivax microsatellite marker. Am J Trop Med Hyg 69: 377-389.

Gopinath R, Wongsrichanalai C, Cordón-Rosales C, Mirabelli L, Kyle D, Kain KC 1994. Failure to detect a Plasmodium vivaxlike malaria parasite in globally collected blood samples. $J$ Infect Dis 170: 1630-1633.

Gosi P, Khusmith S, Khalambaheti T, Lanar D, Schaecher K, Fukuda M, Miller S 2008. Polymorphism patterns in Duffy-binding protein among Thai Plasmodium vivax isolates. Malar J 7: 112.

Grimberg BT, Udomsangpetch R, Xainli J, McHenry A, Panichakul T, Sattabongkot J, Cui L, Bockarie M, Chitnis C, Adams J, Zimmerman PA, King CL 2007. Plasmodium vivax invasion of human erythrocytes inhibited by antibodies directed against the Duffy binding protein. PLoS Med 4: e337.

Grynberg P, Fontes CJF, Hughes AL, Braga EM 2008. Polymorphism at the apical membrane antigen 1 locus reflects the world population history of Plasmodium vivax. BMC Evolutionary Biology 8: 123.

Guerra CA, Howes RE, Patil AP, Gething PW, Van Boeckel TP, Temperley WH, Kabaria CW, Tatem AJ, Manh BH, Elyazar IR, Baird JK, Snow RW, Hay SI 2010. The international limits and population at risk of Plasmodium vivax transmission in 2009. PLoS Negl Trop Dis 4: e774. 
Gunasekera AM, Wickramarachchi T, Neafsey DE, Ganguli I, Perera L, Premaratne PH, Hartl D, Handunnetti SM, Udagama-Randeniya PV, Wirth DF 2007. Genetic diversity and selection at the Plasmodium vivax apical membrane antigen-1 (PvAMA-1) locus in a Sri Lankan population. Mol Biol Evol 24: 939-947.

Gunawardena S, Karunaweera ND, Ferreira MU, Phone-Kyaw M, Pollack RJ, Alifrangis M, Rajakaruna RS, Konradsen F, Amerasinghe PH, Schousboe ML, Galappaththy GN, Abeyasinghe RR, Hartl DL, Wirth DF 2010. Geographic structure of Plasmodium vivax: microsatellite analysis of parasite populations from Sri Lanka, Myanmar, and Ethiopia. Am J Trop Med Hyg 82: 235-242.

Gutierrez A, Vicini J, Patarroyo ME, Murillo LA, Patarroyo MA 2000. Plasmodium vivax: polymorphism in the merozoite surface protein 1 gene from wild Colombian isolates. Exp Parasitol 95: 215-219.

Han ET, Park JH, Shin EH, Choi MH, Oh MD, Chai JY 2002. Apical membrane antigen-1 (AMA-1) gene sequences of re-emerging Plasmodium vivax in South Korea. Korean J Parasitol 40: 157-162.

Han ET, Song TE, Park JH, Shin EH, Guk SM, Kim TY, Chai JY 2004. Allelic dimorphism in the merozoite surface protein-3alpha in Korean isolates of Plasmodium vivax. Am J Trop Med Hyg 71: 745-749.

Han ET, Wang Y, Lim CS, Cho JH, Chai JY 2011. Genetic diversity of the malaria vaccine candidate merozoite surface protein 1 gene of Plasmodium vivax field isolates in Republic of Korea. Parasitol Res [Epub ahead of print]. Available from springerlink.com/content/x085hm23431201g1/.

Hans D, Pattnaik P, Bhattacharyya A, Shakri A, Yazdani S, Sharma M, Choe H, Farzan M, Chitnis C 2005. Mapping binding residues in the Plasmodium vivax domain that binds Duffy antigen during red cell invasion. Mol Microbiol 55: 1423-1434.

Havryliuk T, Ferreira MU 2009. A closer look at multiple-clone Plasmodium vivax infections: detection methods, prevalence and consequences. Mem Inst Oswaldo Cruz 104: 67-73.

Henry-Halldin CN, Sepe D, Susapu M, McNamara DT, Bockarie M, King CL, Zimmerman PA 2011. High-throughput molecular diagnosis of circumsporozoite variants VK210 and VK247 detects complex Plasmodium vivax infections in malaria endemic populations in Papua New Guinea. Infect Genet Evol 11: 391-398.

Hernández-Martínez MA, Escalante AA, Arévalo-Herrera M, Herrera S 2011. Antigenic diversity of the Plasmodium vivax circumsporozoite protein in parasite isolates of Western Colombia. Am J Trop Med Hyg 84: 51-57.

Herrera S, Corradin G, Arévalo-Herrera M 2007. An update on the search for a Plasmodium vivax vaccine. Trends Parasitol 23: 122-128.

Hodder AN, Crewther PE, Anders RF 2001. Specificity of the protective antibody response to apical membrane antigen 1. Infect Immun 69: 3286-3294.

Hoffmann EHE, Ribolla PEM, Ferreira MU 2003. Genetic relatedness of Plasmodium falciparum isolates and the origin of allelic diversity at the merozoite surface protein-1 (MSP-1) locus in Brazil and Vietnam. Malar J 2: 24.

Holder AA 2009. The carboxy-terminus of merozoite surface protein 1: structure, specific antibodies and immunity to malaria. Parasitology 136: 1445-1456.

Huang T, Cheng Q, Allan S, Huang Y 1994. DNA sequencing of circumsporozoite protein genes of Plasmodium vivax from four different countries in west Pacific region: comparative study on the flank sequences. Zhongguo Ji Sheng Chong Xue Yu Ji Sheng Chong Bing Za Zhi 12: 85-92.

Imwong M, Nair S, Pukrittayakamee S, Sudimack D, Williams JT, Mayxay M, Newton PN, Kim JR, Nandy A, Osorio L, Carlton JM, White NJ, Day NPJ, Anderson TJ 2007a. Contrasting genetic structure in Plasmodium vivax populations from Asia and South America. Int J Parasitol 37: 1013-1022.

Imwong M, Pukrittayakamee S, Grüner AC, Rénia L, Letourneur F, Looareesuwan S, White NJ, Snounou G 2005. Practical PCR genotyping protocols for Plasmodium vivax using Pvcs and Pvmsp1. Malar J 4: 20.

Imwong M, Pukrittakayamee S, Looareesuwan S, Poirriez J, Pasvol G, White NJ, Snounou G 2001. Plasmodium vivax: polymerase chain reaction amplification artifacts limit the suitability of pvgam1 as a genetic marker. Exp Parasitol 99: 175-179.

Imwong M, Snounou G, Pukrittayakamee S, Tanomsing N, Kim JR, Nandy A, Guthmann JP, Nosten F, Carlton J, Looareesuwan S, Nair S, Sudimack D, Day NP, Anderson TJ, White NJ 2007b. Relapses of Plasmodium vivax infection usually result from activation of heterologous hypnozoites. J Infect Dis 195: 927-933.

Imwong M, Sudimack D, Pukrittayakamee S, Osório L, Carlton JM, Day NPJ, White NJ, Anderson TJC 2006. Microsatellite variation, repeat array length and population history of Plasmodium vivax. Mol Biol Evol 23: 1016-1018.

Joshi H, Subbarao SK, Raghavendra K, Sharma VP 1989. Plasmodium vivax: enzyme polymorphism in isolates of Indian origin. Trans R Soc Trop Med Hyg 83: 179-181.

Joy DA, Gonzalez-Cerón L, Carlton JM, Gueye A, Fay M, McCutchan TF, Su XZ 2008. Local adaptation and vector-mediated population structure in Plasmodium vivax malaria. Mol Biol Evol 25: 1245-1252.

Kain KC, Brown AE, Mirabelli L, Webster HK 1993. Detection of Plasmodium vivax by polymerase chain reaction in a field study. J Infect Dis 168: 1323-1326.

Karunaweera ND, Ferreira MU, Hartl DL, Wirth DF 2007. Fourteen polymorphic microsatellite DNA markers for the human malaria parasite Plasmodium vivax. Mol Ecol Notes 7: 172-175.

Karunaweera ND, Ferreira MU, Munasinghe A, Barnwell JW, Collins WE, King CL, Kawamoto F, Hartl DL, Wirth DF 2008. Extensive microsatellite diversity in the human malaria parasite Plasmodium vivax. Gene 410: 105-112.

Khatoon L, Baliraine FN, Bonizzoni M, Malik SA, Yan GY 2010. Genetic structure of Plasmodium vivax and Plasmodium falciparum in the Bannu district of Pakistan. Malar J 9: 112.

Kho W, Chung J, Sim E, Kim D, Chung W 2001. Analysis of polymorphic regions of Plasmodium vivax Duffy binding protein of Korean isolates. Korean J Parasitol 39: 143-150.

Kim JR, Imwong M, Nandy A, Chotivanich K, Nontprasert A, Tonomsing N, Maji A, Addy M, Day NP, White NJ, Pukrittayakamee S 2006. Genetic diversity of Plasmodium vivax in Kolkata, India. Malar J 5: 71.

Kim SH, Hwang SY, Shin JH, Moon CS, Kim DW, Kho WG 2009. Molecular genetic characterization of the merozoite surface protein 1 gene of Plasmodium vivax from reemerging Korean isolates. Clin Vaccine Immunol 16: 733-738.

Kimura E, Mattei D, di Santi SM, Scherf A 1990. Genetic diversity in the major merozoite surface antigen of Plasmodium falciparum: high prevalence of a third polymorphic form detected in strains derived from malaria patients. Gene 91: 57-62.

Kirchgatter K, del Portillo HA 1998. Molecular analysis of Plasmodium vivax relapses using the MSP1 molecule as a genetic marker. J Infect Dis 177: 511-515.

Koepfli C, Mueller I, Marfurt J, Goroti M, Sie A, Oa O, Genton B, Beck HP, Felger I 2009. Evaluation of Plasmodium vivax genotyping markers for molecular monitoring in clinical trials. $J$ Infect Dis 199: 1074-1080. 
Kolakovich KA, Ssengoba A, Wojcik K, Tsuboi T, Al-Yaman F, Alpers M, Adams JH 1996. Plasmodium vivax: favored gene frequencies of the merozoite surface protein-1 and the multiplicity of infection in a malaria endemic region. Exp Parasitol 83: 11-18.

Leclerc MC, Durant P, Gauthier C, Patot S, Billote N, Menegon M, Severini C, Ayala FJ, Renaud F 2004. Meager genetic variability of the human malaria agent Plasmodium vivax. Proc Natl Acad Sci USA 101: 14455-14460.

Levinson G, Gutman GA 1987. Slipped-strand mispairing: a major mechanisms for DNA sequence evolution. Mol Biol Evol 4: 203-221.

Lim CS, Kim SH, Kwon SI, Song JW, Song KJ, Lee KN 2000. Analysis of Plasmodium vivax merozoite surface protein-1 gene sequences from resurgent Korean isolates. Am J Trop Med Hyg 62: 261-265.

Lim CS, Tazi L, Ayala FJ 2005. Plasmodium vivax: recent world expansion and genetic identity to Plasmodium simium. Proc Natl Acad Sci USA 102: 15523-15528.

Machado RLD, Póvoa MM 2000. Distribution of Plasmodium vivax variants (VK210, VK247 and P. vivax-like) in three endemic areas of the Amazon Region of Brazil and their correlation with chloroquine treatment. Trans R Soc Trop Med Hyg 94: 377-381.

Maestre A, Sunil S, Ahmad G, Mohmmed A, Echeverri M, Corredor M, Blair S, Chauhan VS, Malhotra P 2004. Inter-allelic recombination in the Plasmodium vivax merozoite surface protein 1 gene among Indian and Colombian isolates. Malar J 3: 4.

Mann VH, Huang T, Cheng Q, Saul A 1994. Sequence variation in the circumsporozoite protein gene of Plasmodium vivax appears to be regionally biased. Mol Biochem Parasitol 68: 45-52.

Martinez P, Suarez CF, Cardenas PP, Patarroyo MA 2004. Plasmodium vivax Duffy binding protein: a modular evolutionary proposal. Parasitology 128: 353-366.

Mascorro CN, Zhao K, Khuntirat B, Sattabongkot J, Yan G, Escalante AA, Cui L 2005. Molecular evolution and intragenic recombination of the merozoite surface protein MSP-3 alpha from the malaria parasite Plasmodium vivax in Thailand. Parasitology 131: 25-35.

McConkey GA, Waters AP, McCutchan TF 1990. The generation of genetic diversity in malaria parasites. Annu Rev Microbiol 44: 479-498.

Michon P, Fraser T, Adams J 2000. Naturally acquired and vaccineelicited antibodies block erythrocyte cytoadherence of the Plasmodium vivax Duffy binding protein. Infect Immun 68: 3164-3171.

Monette M, Opella SJ, Greenwood J, Willis AE, Perham RN 2001. Structure of a malaria parasite antigenic determinant displayed on filamentous bacteriophage determined by NMR spectroscopy: implications for the structure of continuous peptide epitopes of proteins. Protein Sci 10: 1150-1159.

Moon SU, Lee HW, Kim JY, Na BK, Cho SH, Lin K, Sohn WM, Kim TS 2009. High frequency of genetic diversity of Plasmodium vivax field isolates in Myanmar. Acta Trop 109: 30-36.

Moon SU, Na BK, Kang JM, Kim JY, Cho SH, Park YK, Sohn WM, Lin K, Kim TS 2010. Genetic polymorphism and effect of natural selection at domain I of apical membrane antigen-1 (AMA-1) in Plasmodium vivax isolates from Myanmar. Acta Tropica 114: 71-75

Mueller I, Galinski MR, Baird JK, Carlton JM, Kochar DK, Alonso PL, del Portillo HA 2009. Key gaps in the knowledge of Plasmodium vivax, a neglected human malaria parasite. Lancet Infect Dis 9: 555-566.

Mueller I, Kaiok J, Reeder JC, Cortés A 2002. The population structure of Plasmodium falciparum and Plasmodium vivax during an epidemic of malaria in the Eastern Highlands of Papua New Guinea. Am J Trop Med Hyg 67: 459-464.
Nardin EH, Zavala F 1998. Acquired immunity to sporozoites. In IW Sherman, Malaria: parasite biology, pathogenesis, and protection, ASM Press, Washington DC, p. 495-511.

Nogueira PA, Alves FP, Fernandez-Becerra C, Pein O, Santos NR, Pereira da Silva LH, Camargo EP, del Portillo HA 2006. A reduced risk of infection with Plasmodium vivax and clinical protection against malaria are associated with antibodies against the $\mathrm{N}$ terminus but not the $\mathrm{C}$ terminus of merozoite surface protein 1 . Infect Immun 74: 2726-2733.

Oliveira-Ferreira J, Lacerda MV, Brasil P, Ladislau JL, Tauil PL, DanielRibeiro CT, 2010. Malaria in Brazil: an overview. Malar J 9: 115.

Ord R, Polley S, Tami A, Sutherland CJ 2005. High sequence diversity and evidence of balancing selection in the PvMSP3 alpha gene of Plasmodium vivax in the Venezuelan Amazon. Mol Biochem Parasitol 144: 86-93.

Ord RL, Tami A, Sutherland CJ 2008. amal genes of sympatric Plasmodium vivax and $P$. falciparum from Venezuela differ significantly in genetic diversity and recombination frequency. PLoS ONE 3: e3366.

Orjuela-Sánchez P, da Silva NS, da Silva-Nunes M, Ferreira MU 2009a. Recurrent parasitemias and population dynamics of Plasmodium vivax polymorphisms in rural Amazonia. Am J Trop Med Hyg 81: 961-968.

Orjuela-Sánchez P, da Silva-Nunes M, da Silva NS, Scopel KK, Gonçalves RM, Malafronte RS, Ferreira MU 2009b. Population dynamics of genetically diverse Plasmodium falciparum lineages: community-based prospective study in rural Amazonia. Parasitology 136: 1097-1105.

Pacheco MA, Poe AC, Collins WE, Lal AA, Tanabe K, Kariuki SK, Udhayakumar V, Escalante AA 2007. A comparative study of the genetic diversity of the $42 \mathrm{kDa}$ fragment of the merozoite surface protein 1 in Plasmodium falciparum and P. vivax. Infect Genet Evol 7: 180-187.

Pasay MC, Cheng Q, Rzepczyk C, Saul A 1995. Dimorphism of the $\mathrm{C}$ terminus of the Plasmodium vivax merozoite surface protein 1. Mol Biochem Parasitol 70: 217-219.

Patil A, Orjuela-Sánchez P, da Silva-Nunes M, Ferreira MU 2010. Evolutionary dynamics of the immunodominant repeats of the Plasmodium vivax malaria-vaccine candidate circumsporozoite protein (CSP). Infect Genet Evol 10: 298-303.

Pizarro JC, Vulliez-Le Normand B, Chesne-Seck ML, Collins CR, Withers-Martinez C, Hackett F, Blackman MJ, Faber BW, Remarque EJ, Kocken CH, Thomas AW, Bentley GA 2005. Crystal structure of the malaria vaccine candidate apical membrane antigen 1. Science 308: 408-411.

Polley SD, Weedall GD, Thomas AW, Golightly LM, Conway DJ 2005. Orthologous gene sequences of merozoite surface protein 1 (MSP1) from Plasmodium reichenowi and P. gallinaceum confirm an ancient divergence of P. falciparum alleles. Mol Biochem Parasitol 142: 25-31.

Prajapati SK, Joshi H, Valecha N 2010. Plasmodium vivax merozoite surface protein-3 alpha: a high-resolution marker for genetic diversity studies. J Vec Bor Dis 472: 85-90.

Prajapati SK, Verma A, Adak T, Yadav RS, Kumar A, Eapen A, Das MK, Singh N, Sharma SK, Rizvi MA, Dash AP, Joshi H 2006. Allelic dimorphism of Plasmodium vivax gam-1 in the Indian subcontinent. Malar J 5: 90.

Premawansa S, Snewin VA, Khouri E, Mendis KN, David PH 1993. Plasmodium vivax: recombination between potential allelic types of the merozoite surface protein MSP1 in parasites isolated from patients. Exp Parasitol 76: 192-199. 
Price RN, Douglas NM, Anstey NM 2009. New developments in Plasmodium vivax malaria: severe disease and the rise of chloroquine resistance. Curr Opin Infect Dis 22: 430-435.

Putaporntip C, Jongwutiwes S, Grynberg P, Cui L, Hughes AL 2009. Nucleotide sequence polymorphism at the apical membrane antigen-1 locus reveals population history of Plasmodium vivax in Thailand. Infec Gen Evol 9: 1295-1300.

Putaporntip C, Jongwutiwes S, Iwasaki T, Kanbara H, Hughes AL 2006. Ancient common ancestry of the merozoite surface protein 1 of Plasmodium vivax as inferred from its homologue in Plasmodium knowlesi. Mol Biochem Parasitol 146: 105-108.

Putaporntip C, Jongwutiwes S, Sakihama N, Ferreira M, Kho W, Kaneko A, Kanbara H, Hattori T, Tanabe K 2002. Mosaic organization and heterogeneity in frequency of allelic recombination of the Plasmodium vivax merozoite surface protein-1 locus. Proc Natl Acad Sci USA 99: 16348-16353.

Putaporntip C, Jongwutiwes S, Tanabe K, Thaithong S 1997. Interallelic recombination in the merozoite surface protein (MSP-1) gene of Plasmodium vivax from Thai isolates. Mol Biochem Parasitol 84: 49-56.

Qari SH, Collins WE, Lobel HO, Taylor F, Lal AA 1994. A study of polymorphism in the circumsporozoite protein of human malaria parasites. Am J Trop Med Hyg 50: 45-51.

Qari SH, Goldman IF, Povoa MM, di Santi S, Alpers MP, Lal AA 1992. Polymorphism in the circumsporozoite protein of the human malaria parasite Plasmodium vivax. Mol Biochem Parasitol 55: 105-113.

Qari SH, Goldman IF, Povoa MM, Oliveira S, Alpers MP, Lal AA 1991. Wide distribution of the variant form of the human malaria parasite Plasmodium vivax. J Biol Chem 266: 16297-16300.

Qari SH, Shi YP, Goldman IF, Udhayakumar V, Alpers MP, Collins WE, Lal AA 1993a. Identification of Plasmodium vivax-like human malaria parasite. Lancet 341: 780-783.

Qari SH, Shi YP, Povoa MM, Alpers MP, Deloron P, Murphy GS, Harjosuwarno S, Lal AA 1993b. Global occurrence of Plasmodium vivax-like human malaria parasite. J Infect Dis 168: 1485-1489.

Rajesh V, Elamaran M, Vidya S, Gowrishankar M, Kochar D, Das A 2007. Plasmodium vivax: genetic diversity of the apical membrane antigen-1 (AMA-1) in isolates from India. Exp Parasitol 116: $252-256$.

Ranjan A, Chitnis C 1999. Mapping regions containing binding residues within functional domains of Plasmodium vivax and Plasmodium knowlesi erythrocyte-binding proteins. Proc Natl Acad Sci USA 96: 14067-14072.

Rezende AM, Tarazona-Santos E, Couto AD, Fontes CJ, de Souza JM, Carvalho LH, Brito CF 2009. Analysis of genetic variability of Plasmodium vivax isolates from different Brazilian Amazon areas using tandem repeats. Am J Trop Med Hyg 80: 729-733.

Rezende AM, Tarazona-Santos E, Fontes CJ, Souza JM, Couto AD, Carvalho LH, Brito CF 2010. Microsatellite loci: determining the genetic variability of Plasmodium vivax. Trop Med Int Health 15: 718-726.

Rich SM, Ferreira MU, Ayala FJ 2000. The origin of antigenic diversity in Plasmodium falciparum. Parasitol Today 16: 390-396.

Rich SM, Hudson RR, Ayala FJ 1997. Plasmodium falciparum antigenic diversity: evidence of clonal population structure. Proc Natl Acad Sci USA 94: 13040-13045.

Rodrigues MH, Rodrigues KM, Oliveira TR, Cômodo AN, Rodrigues MM, Kocken CH, Thomas AW, Soares IS 2005. Antibody response of naturally infected individuals to recombinant Plasmodium vivax apical membrane antigen-1. Int J Parasitol 35: 185-192.
Rongnoparut P, Supsamran N, Sattabongkot J, Suwanabun N, Rosenberg R 1995. Phenotype and genotype diversity in the circumsporozoite proteins of Plasmodium vivax in Thailand. Mol Biochem Parasitol 74: 201-210.

Rosenberg R, Wirtz RA, Lanar DE, Sattabongkot J, Hall T, Waters AP, Prasittisuk C 1989. Circumsporozoite protein heterogeneity in the human malaria parasite Plasmodium vivax. Science 245: 973-976.

Roy SW, Ferreira MU, Hartl DL 2008. Evolution of allelic dimorphism in malarial surface antigens. Heredity 100: 103-110.

Santos-Ciminera PD, Alecrim MG, Roberts DR, Quinnan GV Jr 2007. Molecular epidemiology of Plasmodium vivax in the state of Amazonas, Brazil. Acta Trop 102: 38-46.

Schlötterer C 1998. Genome evolution: are microsatellites really simple sequences? Curr Biol 8: R132-134.

Silvie O, Franetich JF, Charrin S, Mueller MS, Siau A, Bodescot M, Rubinstein E, Hannoun L, Charoenvit Y, Kocken CH, Thomas AW, Gemert GJv, Sauerwein RW, Blackman MJ, Anders RF, Pluschke G, Maziera D 2004. Role for apical membrane antigen 1 during invasion of hepatocytes by Plasmodium falciparum sporozoites. J Biol Chem 279: 9490-9496.

Singh AP, Ozwara H, Kocken CHM, Puri SK, Thomas AW, Chitnis CE 2005. Targeted deletion of Plasmodium knowlesi Duffy binding protein confirms its role in junction formation during invasion. Mol Microbiol 55: 1925-1934.

Snewin VA, Khouri E, Wattavidanage J, Perera L, Premawansa S, Mendis KN, David PH 1995. A new polymorphic marker for PCR typing of Plasmodium vivax parasites. Mol Biochem Parasitol 71: 135-138.

Soares IS, Barnwell JW, Ferreira MU, Cunha MG, Laurino JP, Castilho BA, Rodrigues MM 1999. A Plasmodium vivax vaccine candidate displays limited allele polymorphism, which does not restrict recognition by antibodies. Mol Medicine 5: 459-470.

Sousa T, Cerávolo I, Fernandes Fontes C, Couto A, Carvalho L, Brito C 2006. The pattern of major polymorphisms in the Duffy binding protein ligand domain among Plasmodium vivax isolates from the Brazilian Amazon area. Mol Biochem Parasitol 146: 251-254.

Sousa TN, Tarazona-Santos EM, Wilson DJ, Madureira AP, Falcão PR, Fontes CJ, Gil LH, Ferreira MU, Carvalho LH, Brito CF 2010. Genetic variability and natural selection at the ligand domain of the Duffy binding protein in Brazilian Plasmodium vivax populations. Malar J 22: 334 .

Storti-Melo LM, de Souza-Neiras WC, Cassiano GC, Joazeiro AC, Fontes CJ, Bonini-Domingos CR, Couto AA, Povoa MM, de Mattos LC, Cavasini CE, Rossit AR, Machado RL 2009. Plasmodium vivax circumsporozoite variants and Duffy blood group genotypes in the Brazilian Amazon Region. Trans R Soc Trop Med Hyg 103: 672-678.

Suh IB, Hoffman KJ, Kim SH, Song KJ, Song JW, Lee JS, Lim CS 2001. The analysis of Plasmodium vivax Duffy receptor binding domain gene sequence from resurgent Korea isolates. Parasitol Res 87: 1007-1010.

Sutton PL, Neyra V, Hernandez JN, Branch OH 2009. Plasmodium falciparum and Plasmodium vivax infections in the Peruvian Amazon: propagation of complex, multiple allele-type infections without super-infection. Am J Trop Med Hyg 816: 950-960.

Thakur A, Alam MT, Bora H, Kaur P, Sharma YD 2008. Plasmodium vivax: sequence polymorphism and effect of natural selection at apical membrane antigen 1 (PvAMA1) among Indian population. Gene 419: 35-42.

Tsuboi T, Kappe SHI, Alyaman F, Prickett MD, Alpers M, Adams JH 1994. Natural variation within the principal adhesion domain of the Plasmodium vivax Duffy binding-protein. Infect Immun 62: 5581-5586. 
Udagama PV, David PH, Peiris JSM, Ariyaratne YG, Perera KLRL, Mendis KN 1987. Demonstration of antigenic polymorphism in Plasmodium vivax malaria with a panel of 30 monoclonal antibodies. Infect Immun 55: 2604-2611.

Udagama PV, Gamage-Mendis AC, David PH, Peiris JS, Perera KLRL, Carter R 1990. Genetic complexity of Plasmodium vivax parasites in individual human infections analyzed with monoclonal antibodies against variant epitopes on a single parasite protein. Am J Trop Med Hyg 42: 101-110.

Udomsangpetch R, Kaneko O, Chotivanich K, Sattabongkot J 2008. Cultivation of Plasmodium vivax. Trends Parasitol 24: 85-88.

Valderrama-Aguirre A, Zúñiga-Soto E, Mariño-Ramírez L, Moreno LA, Escalante AA, Arévalo-Herrera M, Herrera S 2011. Polymorphism of the Pv200L fragment of merozoite surface protein-1 of Plasmodium vivax in clinical isolates from the Pacific coast of Colombia. Am J Trop Med Hyg 84: 64-70.

Van den Eede P, Erhart A, Van der Auwera G, Van Overmeir C, Thang ND, Hung le X, Anné J, D’Alessandro U 2010a. High complexity of Plasmodium vivax infections in symptomatic patients from a rural community in central Vietnam detected by microsatellite genotyping. Am J Trop Med Hyg 82: 223-227.

Van den Eede P, Soto-Calle VE, Delgado C, Gamboa D, Grande T, Rodriguez H, Llanos-Cuentas A, Anné J, D’Alessandro U, Erhart A 2011. Plasmodium vivax sub-patent infections after radical treatment are common in Peruvian patients: results of a 1-year prospective cohort study. PLOS ONE 6: e16257.

Van den Eede P, Van der Auwera G, Delgado C, Huyse T, Soto-Calle VE, Gamboa D, Grande T, Rodriguez H, Llanos A, Anné J, Erhart A, D'Alessandro U 2010b. Multilocus genotyping reveals high heterogeneity and strong local population structure of the Plasmodium vivax population in the Peruvian Amazon. Malar J 9: 151.
VanBuskirk KM, Cole-Tobian JL, Baisor M, Sevova ES, Bockarie M, King CL, Adams JH 2004. Antigenic drift in the ligand domain of Plasmodium vivax Duffy binding protein confers resistance to inhibitory antibodies. J Infect Dis 190: 1556-1562.

Veron V, Legrand E, Yrinesi J, Volney B, Simon S, Carme B 2009. Genetic diversity of msp3 and msp1 b5 markers of Plasmodium vivax in French Guiana. Mal $J$ 8: 40.

Xainli J, Adams J, King C 2000. The erythrocyte binding motif of Plasmodium vivax duffy binding protein is highly polymorphic and functionally conserved in isolates from Papua New Guinea. Mol Biochem Parasitol 111: 253-260.

Yang C, Collins WE, Sullivan JS, Kaslow DC, Xiao L, Lal AA 1999. Partial protection against Plasmodium vivax blood-stage infection in Saimiri monkeys by immunization with a recombinant C-terminal fragment of merozoite surface protein 1 in block copolymer adjuvant. Infect Immun 67: 342-349.

Zakeri S, Barjesteh H, Djadid ND 2006. Merozoite surface protein-3 alpha is a reliable marker for population genetic analysis of Plasmodium vivax. Mal J 5: 53.

Zakeri S, Raeisi A, Afsharpad M, Kakar Q, Ghasemi F, Atta H, Zamani G, Memon MS, Salehi M, Djadid ND 2010. Molecular characterization of Plasmodium vivax clinical isolates in Pakistan and Iran using $P v M S P-1, P v M S P-3$ alpha and $p v c s p$ genes as molecular markers. Parasitol Int 591: 15-21.

Zeyrek FY, Tachibana S, Yuksel F, Doni N, Palacpac N, Arisue N, Horii T, Coban C, Tanabe K 2010. Limited polymorphism of the Plasmodium vivax merozoite surface protein 1 gene in isolates from Turkey. Am J Trop Med Hyg 83: 1230-1237.

Zilversmit M, Hartl DL 2005. Evolutionary history and population genetics of human malaria parasites. In IW Sherman (ed.), Molecular approaches to malaria, Press, Washington DC, 542 pp. 